\title{
Avoiding blistering in Al2O3 deposited on planar and black Si
}

\author{
landolo, Beniamino; Davidsen, Rasmus S.; Hansen, Ole
}

Published in:

Solar Energy Materials and Solar Cells

Link to article, DOI:

10.1016/j.solmat.2018.07.014

Publication date:

2018

Document Version

Peer reviewed version

Link back to DTU Orbit

Citation (APA):

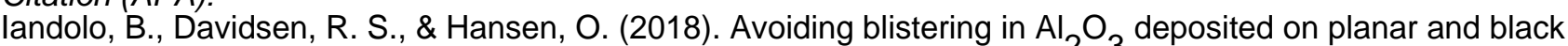
Si. Solar Energy Materials and Solar Cells, 187, 23-29. https://doi.org/10.1616jj.solmat.2018.07.014

\section{General rights}

Copyright and moral rights for the publications made accessible in the public portal are retained by the authors and/or other copyright owners and it is a condition of accessing publications that users recognise and abide by the legal requirements associated with these rights.

- Users may download and print one copy of any publication from the public portal for the purpose of private study or research.

- You may not further distribute the material or use it for any profit-making activity or commercial gain

- You may freely distribute the URL identifying the publication in the public portal

If you believe that this document breaches copyright please contact us providing details, and we will remove access to the work immediately and investigate your claim. 


\title{
Avoiding blistering in $\mathrm{Al}_{2} \mathrm{O}_{3}$ deposited on planar and black $\mathrm{Si}$
}

\author{
Beniamino Iandolo*, Rasmus S. Davidsen, Ole Hansen \\ Department of Micro- and Nanotechnology, Technical University of Denmark, building \\ 345C, DK-2800 Kgs. Lyngby, Denmark \\ ${ }^{*}$ Corresponding author: benian@nanotech.dtu.dk
}

\begin{abstract}
Aluminum oxide $\left(\mathrm{Al}_{2} \mathrm{O}_{3}\right)$ fabricated by atomic layer deposition (ALD) has during the last decade emerged as an excellent surface passivation material for both planar and micro/nanostructured silicon. The post-ALD thermal treatment required to activate the surface passivation of $\mathrm{Al}_{2} \mathrm{O}_{3}$ results often in blistering and film delamination. Here, we studied how several fabrication steps affect blistering and the quality of surface passivation by $\mathrm{Al}_{2} \mathrm{O}_{3}$. Decreasing the fraction of blistered area on planar Si surfaces results in lower surface recombination velocity, in agreement with previous reports. By using simple analytical expressions, we estimated that surface recombination is at least 20 times faster at the blister than at the non-blistered areas. Exposing the Si surface to a reactive ion etch (RIE) treatment as short as $30 \mathrm{~s}$ is enough to suppress blistering. Anti-reflective nanostructured Si (black Si) fabricated using the same RIE process by increasing the RIE time does not suffer from blistering either. Finally, we investigated the effective lifetime of black Si textured surfaces and we implemented a pre-ALD conditioning routine that dramatically improves the quality of passivation by $\mathrm{Al}_{2} \mathrm{O}_{3}$ on black $\mathrm{Si}$.
\end{abstract}

Key Words: surface passivation, $\mathrm{Al}_{2} \mathrm{O}_{3}$, blistering, black silicon 


\section{Introduction}

The power conversion efficiency of silicon ( $\mathrm{Si}$ ) solar cells is severely affected by charge recombination at the surface of Si wafers, which mainly results in a less-than-ideal open circuit voltage [1,2]. Surface passivation is the act of decreasing surface recombination, typically performed by growing or depositing a thin dielectric layer on the surface of Si [3]. Aluminum oxide $\left(\mathrm{Al}_{2} \mathrm{O}_{3}\right)$ has emerged as excellent material for passivation of $\mathrm{Si}$, with performance comparable to or higher than that of thermally grown $\mathrm{Si}$ oxide $\left(\mathrm{SiO}_{2}\right)$ [4]. Low surface recombination velocity has been achieved by depositing $\mathrm{Al}_{2} \mathrm{O}_{3}$ by sputtering $[5,6]$, plasma-enhanced chemical vapor deposition (PECVD) [7-9], and atomic layer deposition (ALD) [10-13]. $\mathrm{Al}_{2} \mathrm{O}_{3}$ and $\mathrm{Al}_{2} \mathrm{O}_{3} / \mathrm{SiN}_{\mathrm{x}}: \mathrm{H}$ stacks are already industrially relevant for: (i) rear side passivation of cells based on p-type substrates [14], thus replacing the traditional Al back surface field, and (ii) passivation of $\mathrm{p}^{+}$emitters in cells based on n-type substrates $[15,16]$. $\mathrm{Al}_{2} \mathrm{O}_{3}$ has also demonstrated outstanding passivation performance when deposited on nanostructured, naturally antireflective Si (usually referred to as black Si [17], hereinafter bSi) $[18,19]$. The characteristic dimension of nanostructures in bSi leads to suppression of optical reflectance at the air-Si interface [20]. This in turn relaxes requirements on the antireflective properties of passivation films. If leading to enhanced photon absorption as compared to conventional texturing, higher short circuit current may also be obtained [21]. In addition, it has been shown that reflection off cells based on bSi surfaces is less affected by the increase in incidence angle, which is particularly relevant for building-integrated applications [22,23]. bSi suffers from higher surface recombination given the increased surface area and the subsurface damage originated by the texturing process (the latter when fabricated by reactive ion etch - RIE) [24], leading to losses in terms of open circuit voltage and fill factor. However, the gap between efficiency of bSi based cells and that of conventionally textured cells under same fabrication conditions is progressively closing [16], and the best passivation of bSi has been achieved so far by ALD coating with $\mathrm{Al}_{2} \mathrm{O}_{3}$ [25].

A post-ALD thermal treatment in inert or slightly reducing atmosphere is mandatory to activate the passivation by $\mathrm{Al}_{2} \mathrm{O}_{3}$ [4]. After such treatments, blistering is very often observed at the $\mathrm{Si}-\mathrm{Al}_{2} \mathrm{O}_{3}$ interface, sometimes leading to partial delamination of the $\mathrm{Al}_{2} \mathrm{O}_{3}$ film [26-28]. Possible explanations put forward to explaining formation of blisters are cavitation of the substrate caused by the surface diffusion of $\mathrm{Si}$ atoms, followed by buckling of the $\mathrm{Al}_{2} \mathrm{O}_{3}$ after a critical internal pressure is reached [29-31] and mechanical shear stress due to thermal mismatch between $\mathrm{Si}$ and $\mathrm{Al}_{2} \mathrm{O}_{3}$ during annealing [32]. The presence of $\mathrm{SiN}_{\mathrm{x}}: \mathrm{H}$ as capping 
layer does not seem to avoid blistering [33], which is also found on surfaces textured by $\mathrm{KOH}$ (i.e. pyramid textured surfaces) [32]. While Vermang et al. showed that it is possible to exploit the presence of blisters to create local openings at the rear of a cell during contact firing [34], it is generally believed that blistering should be avoided if possible, in order to have a better control of the rear passivation. In addition, the quality of passivation of $\mathrm{Al}_{2} \mathrm{O}_{3}$ is likely to be affected by the presence of blisters. A few studies reported variations of effective surface recombination velocity $\left(S_{\text {eff }}\right)$ with varying amount of blistering $[32,35]$, based on effective lifetime ( $\left.\tau_{\text {eff }}\right)$ measurements using by quasi-steady state photoconductance method, and therefore averaged on full size wafers. In addition, experimental direct evidence that the local quality of the passivation is degraded at the blisters is difficult to obtain, although such an effect is expected. Several strategies have been employed to reduce blistering at the $\mathrm{Si} / \mathrm{Al}_{2} \mathrm{O}_{3}$ interface, including: decreasing the $\mathrm{Al}_{2} \mathrm{O}_{3}$ thickness [33]; depositing the $\mathrm{Al}_{2} \mathrm{O}_{3}$ at higher temperature, or letting the temperature rise during ALD (i.e. thermal drift ALD) [36]; using $\mathrm{O}_{3}$ as oxygen precursor instead of $\mathrm{H}_{2} \mathrm{O}$ [27]; depositing $\mathrm{Al}_{2} \mathrm{O}_{3}$ on a hydrophilic surface such as a chemically grown $\mathrm{SiO}_{2}$ layer [26]; varying the post-ALD thermal treatment temperature [27]. In all these cases, decreased blistering was attributed to the lower content of hydrogen in the films and/or the facilitated effusion of hydrogen from the films. However, hydrogen is also known as an excellent passivation agent for both bulk and surface defects in $\mathrm{Si}$, and treatment in atmospheres containing hydrogen are routinely used to reduce recombination in Si solar cells. It follows that the gain in surface passivation by avoiding blistering should not be counteracted by any decrease in passivation due to lower content of hydrogen.

Here, we investigated the effect of several fabrication steps (pre-ALD cleaning, ALD temperature, post-ALD thermal treatment) on blistering and on the quality of surface passivation offered by $\mathrm{Al}_{2} \mathrm{O}_{3}$ films. Based on electron microscopy images to determine the surface coverage of blisters and on a simple analytical model, we estimated the local recombination velocity at the blisters $S_{\mathrm{b}}$, and we found that it is at least 20 times higher than that of the non-blistered areas. We found that exposing the Si surface to a $30 \mathrm{~s}$ reactive ion etch (RIE) treatment is enough to suppress blistering completely. Importantly, such a process does not increase $S_{\text {eff }}$ within experimental deviations, and can be used as an alternative to the modifications to ALD and post-ALD processing that result in a lower content of hydrogen as side effect. We used the same RIE process to fabricate bSi textured surfaces, by increasing the RIE time, and we found that no bSi surfaces suffered from blistering either. Finally, we 
investigated the effective lifetime of bSi surfaces and the effect of pre-conditioning of the ALD chamber on the quality of the passivation by $\mathrm{Al}_{2} \mathrm{O}_{3}$ on $\mathrm{bSi}$.

\section{Experimental Section}

\subsection{Fabrication}

$100 \mathrm{~mm}$ diameter Czochralski (CZ) mono-crystalline (100) p-type boron-doped Si wafers with thickness $525 \pm 25 \mu \mathrm{m}$ or $350 \pm 25 \mu \mathrm{m}$ and resistivity of $5 \Omega \mathrm{cm}$ were used as substrates. Some wafers were textured on one side using mask-less reactive ion etch (RIE) at $-20{ }^{\circ} \mathrm{C}$ in a Pegasus system (SPTS) using the following parameters: $3000 \mathrm{~W}$ coil power, $10 \mathrm{~W}$ platen power (both operating at $13.56 \mathrm{MHz}$ ), gas flow ratio $\mathrm{O}_{2}: \mathrm{SF}_{6} \approx 10: 7$, chamber pressure of 34 mTorr. The etching time varied from $30 \mathrm{~s}$ to 16 min depending on the wafer. All wafers were then RCA (Radio Corporation of America) cleaned (RCA1: 1:1:5 mixture of $\mathrm{H}_{2} \mathrm{O}_{2}, \mathrm{NH}_{4} \mathrm{OH}$ solution and de-ionized water; RCA2: 1:1:5 mixture of $\mathrm{H}_{2} \mathrm{O}_{2}, \mathrm{HCl}$ solution and de-ionized water; both solutions were heated to $70{ }^{\circ} \mathrm{C}$ ). For some wafers, the final oxide strip in $5 \%$ diluted hydrofluoric acid (HF) was omitted, in order to keep the $\mathrm{SiO}_{2}$ from the second part of the cleaning on the surface. The surfaces were passivated with 380 cycles of $\mathrm{Al}_{2} \mathrm{O}_{3}$ synthesized at 200 or $250{ }^{\circ} \mathrm{C}$ in an atomic layer deposition (ALD) process (R200, Picosun). Trimethyl-aluminum (TMA) and $\mathrm{H}_{2} \mathrm{O}$ were used as precursors for aluminum and oxygen, respectively. In some cases, a chamber preconditioning procedure was employed where 50 cycles were deposited on the wafer holder without any wafer in the chamber. The $\mathrm{Al}_{2} \mathrm{O}_{3}$ layers were activated by post-deposition treatment. Some wafers were annealed in a $\mathrm{N}_{2}$ atmosphere using a Tempress furnace. Annealing temperature was either $400{ }^{\circ} \mathrm{C}$ or $500{ }^{\circ} \mathrm{C}$, and the annealing time was either 10 or $30 \mathrm{~min}$. The other wafers received a rapid thermal annealing at $400{ }^{\circ} \mathrm{C}$ or $500{ }^{\circ} \mathrm{C}$ in a Jipelec RTP tool. The ramp-up time, annealing time and ramp-down time were $1 \mathrm{~min}, 5 \mathrm{~min}$ and $1 \mathrm{~min}$, respectively.

\subsection{Characterization}

The thickness of the $\mathrm{Al}_{2} \mathrm{O}_{3}$ layer was measured using ellipsometry (VASE J. A.Woollam Co.). Scanning electron microscopy (SEM) images were acquired using a Carl Zeiss Supra 40VP microscope at an acceleration voltage of $5 \mathrm{kV}$. Size and surface coverage of the blisters were calculated from top-view SEM images using the image analysis software ImageJ. Optical reflectance $R$ and transmittance $T$ were measured using a UV spectrophotometer (UV-2600, Shimadzu Co.). The absorptance $A$ was then determined using the relation $A=1-R-T$. Effective lifetime measurements were performed using the microwave-detected 
photoconductivity (MDP) method in transient single point and mapping mode, at an injection level $\Delta n$ of $\sim 10^{15} \mathrm{~cm}^{-3}$, using a MDP mapper (Freiberg Instruments). For symmetrical, nontextured wafers, the effective surface recombination was calculated using the relation $S_{\text {eff }}=$ $W /\left(2 \tau_{\text {eff }}\right)$, where $\mathrm{W}$ is the wafer thickness and $\tau_{\text {eff }}$ is the effective lifetime. $S_{\text {eff }}$ was then used to calculate the surface recombination velocity of the textured surface according to the relation: $S_{\text {textured }}=W / \tau_{\text {eff }}-S_{\text {planar }}$.

\section{Results and Discussion}

\subsection{Blistering in $\mathrm{Al}_{2} \mathrm{O}_{3}$ on flat $\mathrm{Si}$}

We fabricated a first set of wafers to test the effect of ALD deposition temperature and furnace annealing on formation of blisters on surfaces which have been cleaned following the complete RCA procedure, including the final oxide strip using 5\% diluted HF. The $\mathrm{Al}_{2} \mathrm{O}_{3}$ thickness was fixed to $30 \mathrm{~nm}$. Previous work using our ALD reactor, as well as by other groups [18,37], indicated that such thickness is required to passivate bSi well. We chose ALD deposition temperatures of 200 and $250{ }^{\circ} \mathrm{C}$, since these temperatures usually define the window resulting in higher quality of passivation [4]. We followed the same reasoning for the post-ALD annealing temperature, $400{ }^{\circ} \mathrm{C}$ or $500{ }^{\circ} \mathrm{C}$. We annealed the wafers for $30 \mathrm{~min}$ and 5 min at $400{ }^{\circ} \mathrm{C}$ and $500{ }^{\circ} \mathrm{C}$, respectively, so that all wafers would remain in the furnace for approximately the same time. This is because the idle temperature of the furnace is $400{ }^{\circ} \mathrm{C}$ and the ramp-up and ramp-down time for the process is of $10{ }^{\circ} \mathrm{C} \mathrm{min}^{-1}$. Figure 1 shows topview low magnification SEM images of 4 wafers with different combinations of $T_{\mathrm{ALD}}$ and annealing conditions. All surfaces suffer from severe blistering, with blister diameter of up to $100 \mu \mathrm{m}$. It appears that the wafer with $T_{\mathrm{ALD}}=200{ }^{\circ} \mathrm{C}$ and $T_{\mathrm{ann}}=400{ }^{\circ} \mathrm{C}$ suffers from slightly less pronounced blistering. This in contrast with previous reports where it was found that higher ALD and post-ALD processing temperatures lead to less severe blistering thanks to the lower content of hydrogen in the $\mathrm{Al}_{2} \mathrm{O}_{3}[27,36]$. Nonetheless, significant amount of blistering such the one observed here is to be avoided when using $\mathrm{Al}_{2} \mathrm{O}_{3}$ as e.g. rear passivation layer. In addition, we measured effective lifetime values between 52.7 and $74.1 \mu$ s, which is more than an order of magnitude lower than what routinely achieved with $\mathrm{Al}_{2} \mathrm{O}_{3}$. 

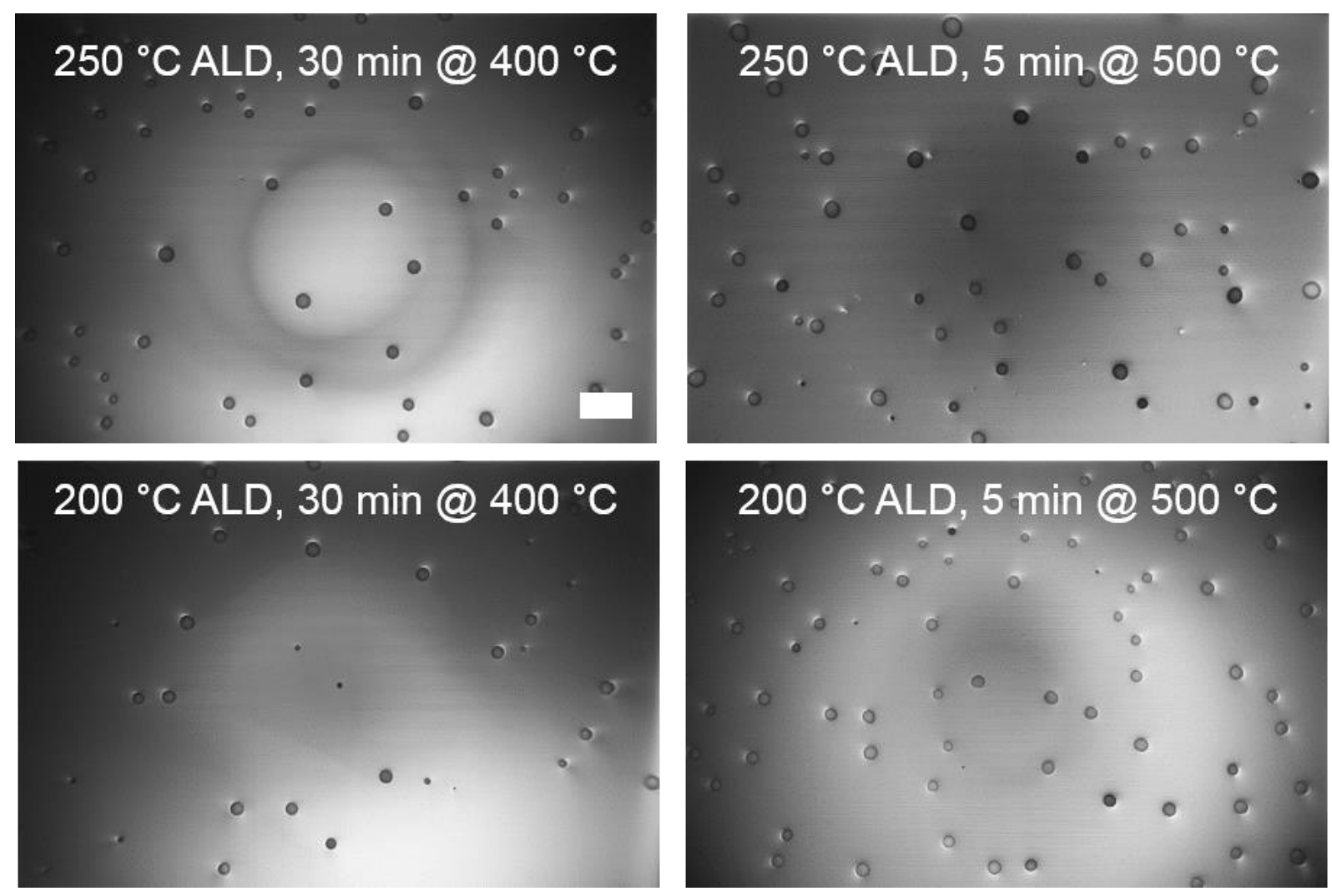

Figure 1. Top-view, small magnification SEM images of flat wafers after RCA cleaning (including last $\mathrm{HF}$ dip), $\mathrm{Al}_{2} \mathrm{O}_{3}$ deposition and annealing in a tube furnace. Blistering is critical on these wafers, with diameter up to around $100 \mu \mathrm{m}$. The scale bar represents $200 \mu \mathrm{m}$.

We fabricated a second set of samples with $T_{\mathrm{ALD}}=200^{\circ} \mathrm{C}$, and with the following modifications. First, we omitted the last dip in 5\% HF during RCA cleaning of all wafers. Second, we annealed two wafers using RTP instead of the tube furnace. RTP allows for much higher ramp-up rates than tube furnaces and therefore for faster processing times per wafer. However, the RTP system available for this study allowed for loading of one full sized wafer at the time, which results in lower throughput. SEM imaging of these wafer reveal much smaller blister size as compared to the surfaces with complete RCA cleaning, as shown in Figure 2. This is in agreement with previous work demonstrating that leaving a hydrophilic surface before ALD lead to smaller blister size [26]. Interestingly, RTP annealed samples appear to have higher number density of blisters and smaller blister diameter as compared with the tube furnace annealed samples. Table 1 summarizes our analysis of blistering on these wafers, as well as measurements of minority carrier effective lifetime $\tau_{\text {eff. }}$ An upper bound for the effective surface recombination velocity $S_{\text {eff }}$ is calculated from $\tau_{\text {eff }}$ under the assumption of negligible bulk recombination using the relation $S_{\text {eff }}=W /\left(2 \tau_{\text {eff }}\right)$, where $W$ is 
the wafer thickness. Increasing $T_{\text {ann }}$ from $400{ }^{\circ} \mathrm{C}$ to $500{ }^{\circ} \mathrm{C}$ and replacing furnace annealing with RTP annealing has two effects: (i) the average diameter of blisters decreases, and (ii) the number density of blisters increases. The resulting surface coverage of blisters is between $0.71 \%$ and $1.77 \%$. It is worth mentioning that the wafer with lowest $S_{\text {eff }}$ is also the one with lowest surface coverage of blisters $f$. Combining data on the surface coverage of blisters with

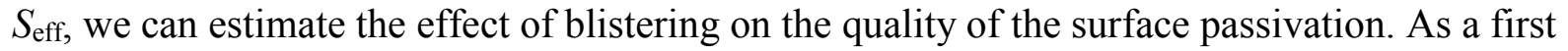
approximation, we can divide $S_{\text {eff }}$ in the sum of the contributions from blistered areas and non-blistered areas:

$$
S_{\text {eff }}=f \times S_{b}+(1-f) \times S_{0}
$$

where $S_{\mathrm{b}}$ is the recombination velocity on the blisters and $S_{0}$ is the recombination velocity away from the blisters. Here no spatial variation in the values of $S_{\mathrm{b}}$ and $S_{0}$ is assumed. In addition, we note that $S_{0}$ is a constant regardless of the surface, which may not necessarily be the case given the different annealing conditions, while $S_{\mathrm{b}}$ is sample dependent. Plotting $S_{\text {eff }}$ as function of $f$ and fitting linearly yields a value of $S_{0}$ of $36.7 \pm 5.5 \mathrm{~cm} \mathrm{~s}^{-1}$. Then we can substitute $S_{0}$ and obtain $S_{\mathrm{b}}$ for each surface. This results in values of $S_{\mathrm{b}}$ between $726 \mathrm{~cm} \mathrm{~s}^{-1}$ and $1043 \mathrm{~cm} \mathrm{~s}^{-1}$, at least 20 times higher than $S_{0}$, and similar to those of Si surfaces before passivation. This confirms that the quality of passivation at the blisters is severely degraded, regardless of whether delamination of the $\mathrm{Al}_{2} \mathrm{O}_{3}$ is present or not. In fact, even such low surface coverage of blisters results in an increase of $S_{\text {eff }}$ of at least $17 \%$. A more rigorous treatment that takes into account diffusion of minority carriers to the blistered areas leads to a modification of the expression for $S_{\text {eff. }}$ The treatment is presented in the Supporting Information. Here, we assume $S_{\mathrm{b}}>>S_{0}$, and $S_{0}$ is sample dependent. For each surface, $S_{\text {eff }}$ can then be written as

$$
S_{\text {eff }}=(1-\sqrt{f})^{2} \times S_{0}+\frac{4 D}{\sqrt{\pi}} \sqrt{N f}
$$

Where $D$ is the diffusivity of minority carriers in Si and $N$ is the number density of blisters. The values of $S_{0}$ are between $35.5 \mathrm{~cm} \mathrm{~s}^{-1}$ and $43.7 \mathrm{~cm} \mathrm{~s}^{-1}$ for the different surfaces, which are at least an order of magnitude lower than those of $S_{\mathrm{b}}$ estimated with the cruder model, thus ensuring self-consistency of the procedure. We also note that these values are close to the number for $S_{0}$ extracted from the $S_{\text {eff }}(f)$ linear fit. In general, we note that the combination of Equations (1) and (2) can be used to extract quantitative information on the local variation of the surface recombination velocity at damaged areas, e.g., blisters, provided that the surface recombination velocity of the damaged areas is much larger than that of the non-damaged areas. This can be useful to quantify the effect of local failure of passivation films when 
measuring effective lifetime with e.g. the quasi-steady state photoconductance method, where the whole surface is illuminated at the same time, or when using the microwave detected photoconductance method and the spatial resolution of the equipment is not sufficient to resolve local variations on the sub- $\mu \mathrm{m}$ scale, such as in this case.
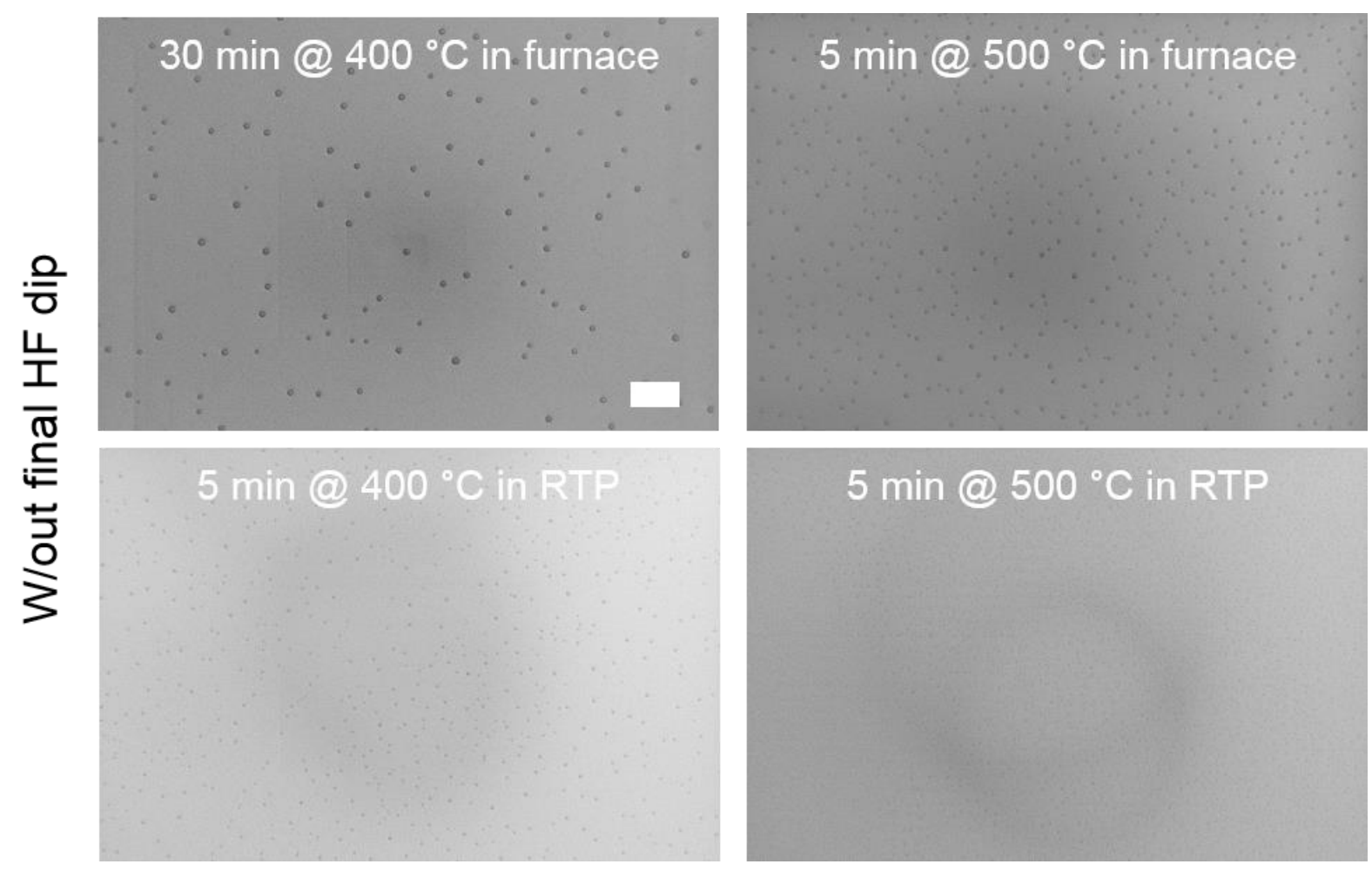

Figure 2. Top-view, small magnification SEM images of flat wafers after RCA cleaning (without last $\mathrm{HF}$ dip), $\mathrm{Al}_{2} \mathrm{O}_{3}$ deposition and annealing in a tube furnace. Post-ALD treatment at $500{ }^{\circ} \mathrm{C}$ results in a higher number density of smaller blisters as compared to treatment at $400{ }^{\circ} \mathrm{C}$. The scale bar represents $200 \mu \mathrm{m}$.

\begin{tabular}{|c|c|c|c|c|c|}
\hline Post-ALD treatment & $\begin{array}{c}\text { Average blister } \\
\text { diameter } \\
(\mu \mathrm{m})\end{array}$ & $\begin{array}{c}\text { Blister number } \\
\text { density } \\
\left(\mathbf{1 0}^{3} \mathbf{~ m m}^{-2}\right) \\
\end{array}$ & $\begin{array}{c}\text { Blister surface } \\
\text { coverage } \\
(\%) \\
\end{array}$ & $\begin{array}{c}S_{\text {eff }} \\
\left(\mathrm{cm} \mathrm{s}^{-1}\right)\end{array}$ & $\begin{array}{c}S_{0} \\
\left(\mathrm{~cm} \mathrm{~s}^{-1}\right)\end{array}$ \\
\hline 30 min @ $400{ }^{\circ} \mathrm{C}$ (furnace) & 25.0 & 2.0 & 0.71 & $43.0 \pm 11.9$ & $35.9 \pm 11.5$ \\
\hline $5 \min @ 500{ }^{\circ} \mathrm{C}$ (furnace) & 14.3 & 6.2 & 1.77 & $51.5 \pm 14.3$ & $41.6 \pm 14.7$ \\
\hline $5 \min @ 400{ }^{\circ} \mathrm{C}(\mathrm{RTP})$ & 9.3 & 14.6 & 1.54 & $52.5 \pm 12.2$ & $43.7 \pm 11.9$ \\
\hline $5 \min @ 500{ }^{\circ} \mathrm{C}(\mathrm{RTP})$ & 4.8 & 54.7 & 1.45 & $47.0 \pm 6.2$ & $37 \pm 7.1$ \\
\hline
\end{tabular}


Table 1. Quantitative analysis of blistering on wafers with different annealing conditions. The right-most columns shows average values of effective surface recombination velocity on 100 $\mathrm{mm}$ diameter wafers $\left(S_{\text {eff }}\right)$, and of surface recombination velocity away from the blistered areas $\left(S_{0}\right)$.

\subsection{Effect of annealing time and of short RIE on blistering}

We observed a further slight decrease in number density of blisters by decreasing $t_{\text {ann }}$ from 30 min to $10 \mathrm{~min}$, as shown in Figure 3(a). However, this does not lead to a decrease in $S_{\text {eff, }}$ which actually increases from 43 to $47.9 \mathrm{~cm} \mathrm{~s}^{-1}$. If we accept the hypothesis that blistering occurs by cavitation followed by delamination and buckling, a rougher Si surface might impede delamination and result in lower blistering. In order to obtain a rougher Si surface, we employed a mask-less RIE process as described in Methods, with a short $t_{\mathrm{RIE}}(30 \mathrm{~s})$. Such a RIE process is designed to produce black silicon texturing consisting of conical-like hillocks approximately 200-400 $\mathrm{nm}$ in height and width (for $t_{\mathrm{RIE}}>10 \mathrm{~min}$ ) yielding ultra-low optical reflectance. Indeed, we observed no blistering when the wafers were exposed to a $30 \mathrm{~s}$ RIE treatment before ALD coating and annealing (see Figure 3(b)). Higher magnification top-view SEM images reveal that the short RIE treatment results in a grainy surface due to the formation of initial etching pits. The quality of the subsequent passivation is only slightly affected by the RIE treatment, as shown in Figure 3(d). We speculate that the increased roughness reduces shear stress at the interface as a driving force for blistering/delamination. In perspective, this finding could make a short RIE treatment before deposition of passivation stacks that include $\mathrm{Al}_{2} \mathrm{O}_{3}$ interesting to inhibit blistering and film delamination. $\mathrm{RIE}$ is a single side processing which makes it possible to use different processes on each side of the cell, e.g. a process resulting in bSi on the front for low reflectance of incident light and a shorter process on the back resulting in high internal reflectance. To this extent, it may be of interest to reduce $t_{\mathrm{RIE}}$ further to find the minimum time required to eliminate blistering. 


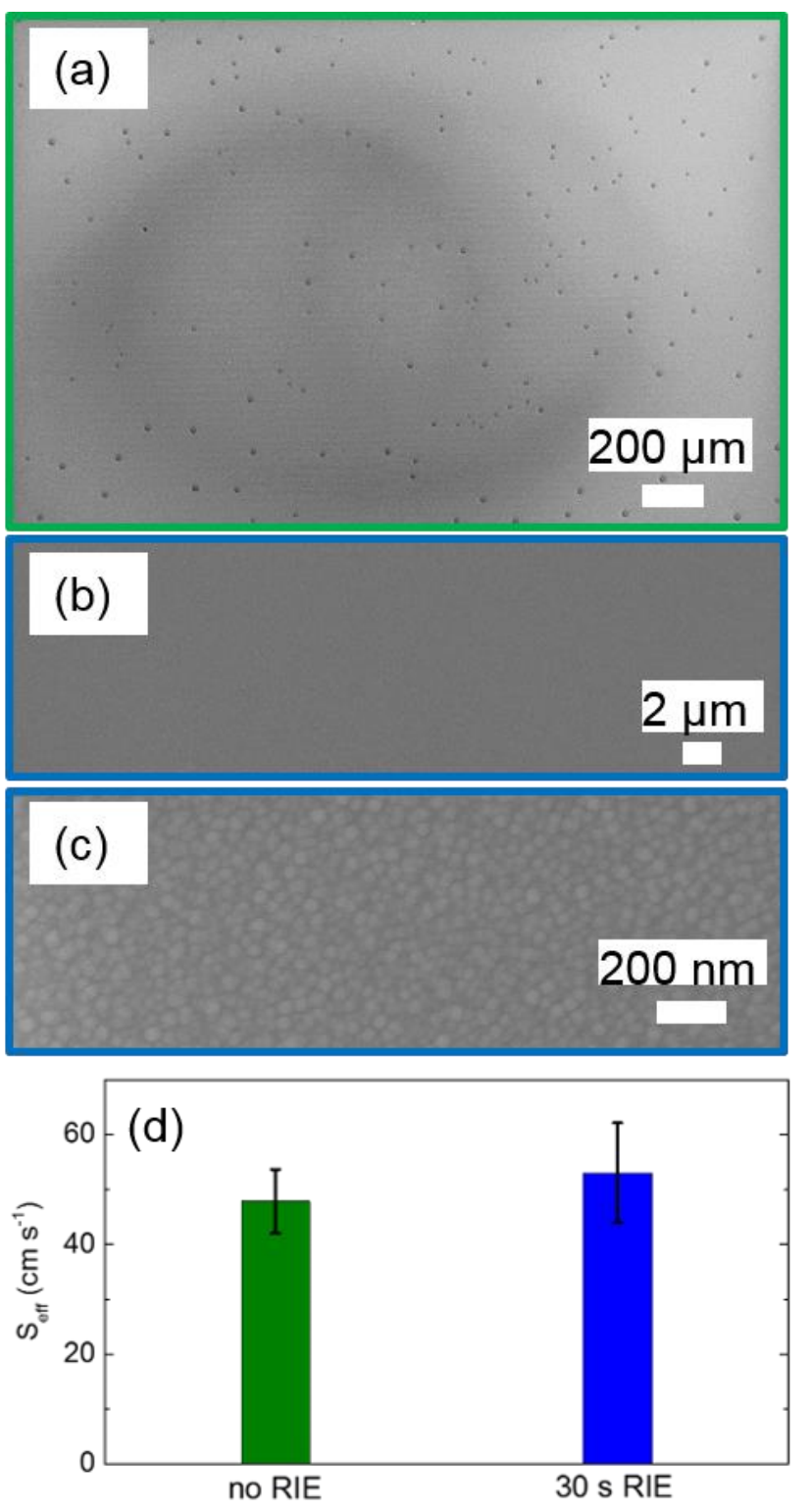

Figure 3. (a) Top-view SEM image of a wafer annealed for $10 \mathrm{~min}$ at $400{ }^{\circ} \mathrm{C}$. (b) Top-view SEM image of a wafer with surface etched for $30 \mathrm{~s}$ by RIE, and annealed for $10 \mathrm{~min}$ at 400 ${ }^{\circ} \mathrm{C}$. Blistering is absent on this surface. (c). Higher magnification image of the same sample as in (b). Grains with approximate diameter between 20 and $50 \mathrm{~nm}$ are visible. (d) $S_{\text {eff }}$ comparison between wafer with no RIE and wafer with 30 s RIE. The $S_{\text {eff }}$ of the etched wafer is slightly higher; however, the average values are not separated by one standard deviation.

\section{5 $\mathrm{Al}_{2} \mathrm{O}_{3}$ on black $\mathrm{Si}$ - effect of RIE time and of chamber preconditioning}

The RIE process used for the sample textured earlier can lead to formation of bSi by increasing $t_{\mathrm{RIE}}$. The presence of nanostructures with characteristic dimensions comparable to the wavelength of UV-vis-NIR photons leads to suppression of optical reflectance at the air-Si interface. Figure 4 summarizes our SEM characterization of Si surfaces textured for $t_{\mathrm{RIE}}$ 
increasing from $30 \mathrm{~s}$ to $16 \mathrm{~min}$. As mentioned earlier, $30 \mathrm{~s}$ of RIE processing is sufficient to observe the formation of etching pits, however with no long-range order in their position. This is in agreement with the current understanding of the formation of $\mathrm{bSi}$, where the first step consists of removal of the native Si oxide at slightly different etch rates depending on random spatial variation on thickness and density of the oxide [38]. For etching time of $3 \mathrm{~min}$, the etching pits begin to overlap with each other resulting in hillock-shaped structures in the Si. Further etching results in an increase in hillock height and average base area. Surface features become smoother upon coating with $\mathrm{Al}_{2} \mathrm{O}_{3}$, as visible from top-view images in the middle row. The cross-section images confirm that the $\mathrm{Al}_{2} \mathrm{O}_{3}$ coating is conformal, as expected when using ALD. From $t_{\mathrm{RIE}} \geq 4 \mathrm{~min}$, the hillocks are more easily defined from the bulk Si. The height of the nanostructures then increases from less than $150 \mathrm{~nm}$ to about $450 \mathrm{~nm}$ for the longest etching time of $16 \mathrm{~min}$. Importantly, no textured sample suffers from blistering, in agreement with results described in the previous section. Increasing $t_{\mathrm{RIE}}$ leads to a dramatic decrease in optical reflectance, as shown in Figure 5(a). There is basically no difference between the reflectance of the planar surface and that of $t_{\mathrm{RIE}}=30 \mathrm{~s}$, after coating with $\mathrm{Al}_{2} \mathrm{O}_{3}$. In both cases, $R$ converges to $30 \%$ for photon wavelength close to the bandgap of $\mathrm{Si}$, a value similar to that of a planar Si surface. Instead, $R$ is lower than that of a Si surface for wavelength shorter than $1000 \mathrm{~nm}$, indicating that the $\mathrm{Al}_{2} \mathrm{O}_{3}$ coating have already a certain antireflective effect, although not as good as for e.g. $\mathrm{SiN}_{\mathrm{x}}: \mathrm{H}$, which has a better refractive index match with Si. Increasing $t_{\mathrm{RIE}}$ to $1 \mathrm{~min}$ and $2 \mathrm{~min}$
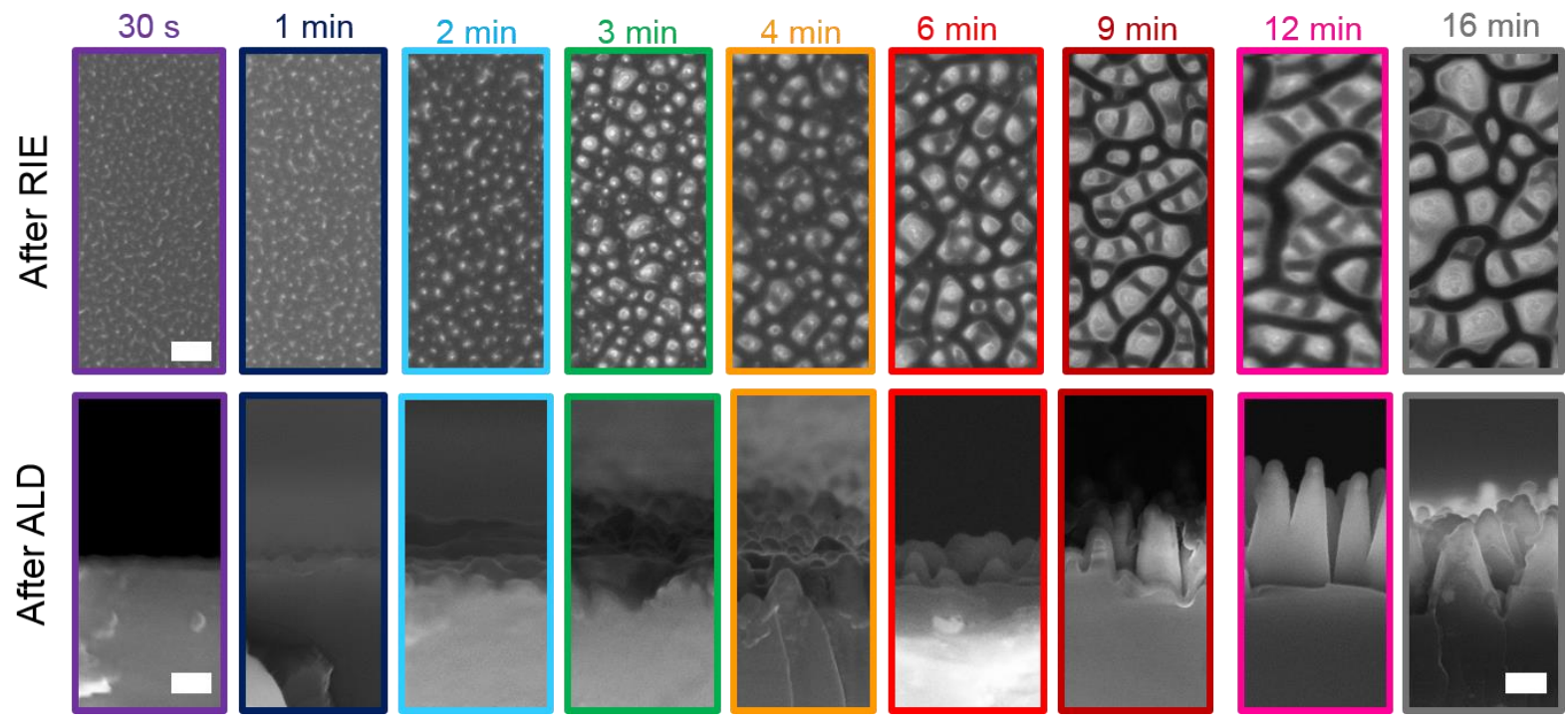

Figure 4. SEM characterization of wafers with front size texturing by RIE. Top row: top-view SEM images of wafers with different $t_{\mathrm{RIE}}$. Bottom row: cross-section SEM images of the same 
wafers. The scale bar represents $100 \mathrm{~nm}$ for all images except for $t_{\mathrm{RIE}}=16 \mathrm{~min}$, where the scale bar represents $200 \mathrm{~nm}$.

leads to a sizeable decrease in $R$, down to about $8 \%$ for $t_{\mathrm{RIE}}=2 \min$ around $400 \mathrm{~nm}$. The reflectance reaches almost $30 \%$ close to the bandgap of Si for these wafers as well. For $t_{\mathrm{RIE}} \geq$ $6 \mathrm{~min}$, the spectra resemble much more closely those measured by others on bSi fabricated by RIE [25,37,39]. $R$ is lower than $5 \%$ for wavelength up to almost $1050 \mathrm{~nm}$, after which $R$ increases steeply reaching $20 \%$ at $1200 \mathrm{~nm}$. The transmittance $T$ in the wavelength range 1000-1200 nm is plotted in Fig. 5(b). $T$ decreases slightly for increasing $t_{\mathrm{RIE}}$, and the largest decrease takes place from $t_{\mathrm{RIE}}=12 \mathrm{~min}$ to $t_{\mathrm{RIE}}=16$
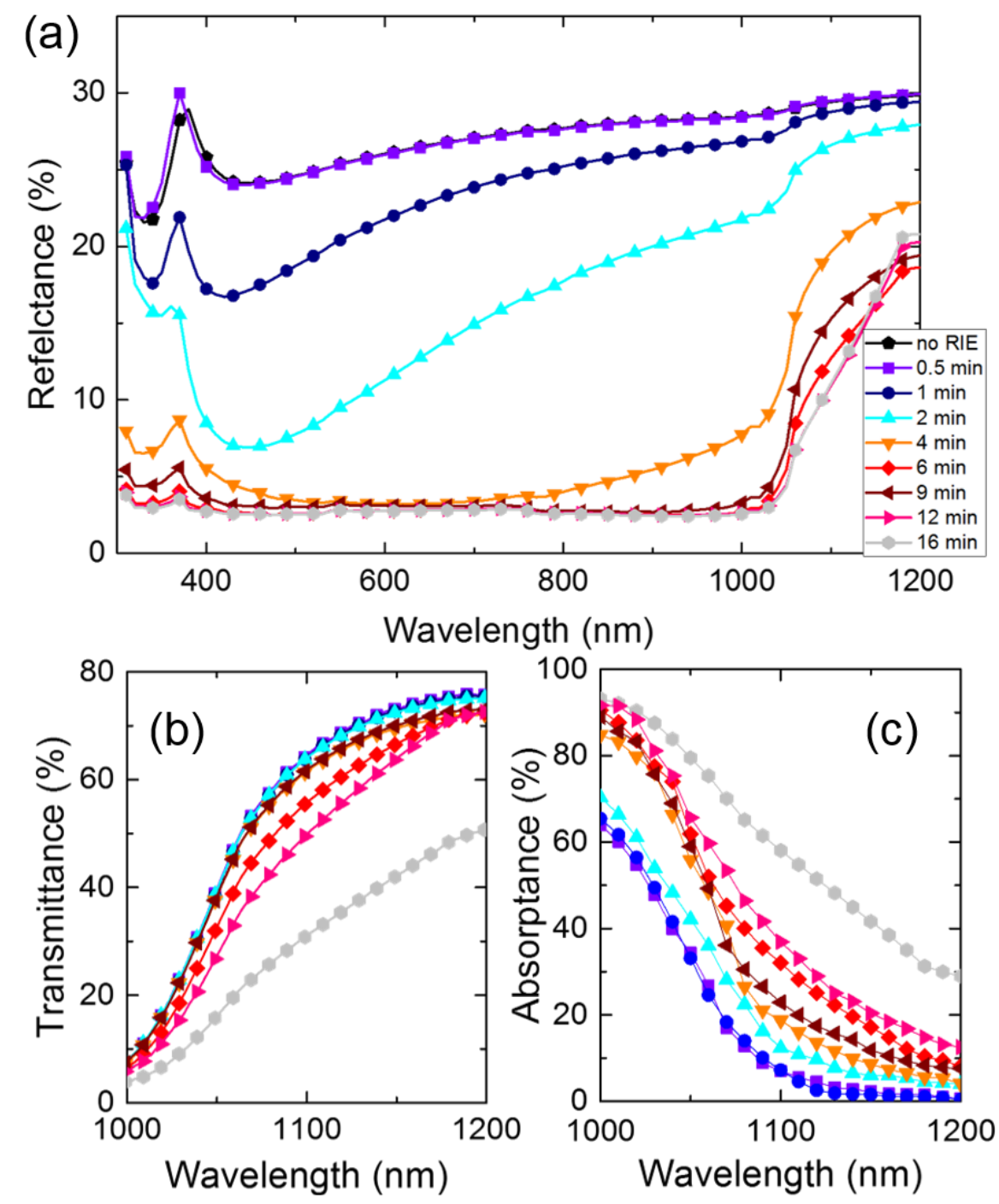

Figure 5. Optical properties for surfaces textured for different $t_{\mathrm{RIE}}$. (a) Reflectance. (b)

Transmittance. (c) Absorptance. The legend is the same for all plots. 
$\min$. For $t_{\mathrm{RIE}}=16 \mathrm{~min}, T$ approaches values normally obtained using upright $\mathrm{KOH}$ textured pyramids, which indicates that the light trapping ability of our bSi can be similar to that of $\mathrm{KOH}$ textured samples, if $t_{\mathrm{RIE}}$ is sufficiently long. The absorptance can then be calculated using the relation $A=1-R-T$, and it is plotted in Fig. 5(c). Clearly, $A$ follows the opposite trend of $R$ and $T$, with increasing $A$ for increasing $t_{\mathrm{RIE}}$.

The surface recombination velocity of the textured surface $S_{\text {textured }}$ is plotted as function of $t_{\mathrm{RIE}}$ in Figure 6 for two batches of wafers. In one of them, we introduced an ALD chamber preconditioning routine consisting in depositing 50 cycles of $\mathrm{Al}_{2} \mathrm{O}_{3}$ in the chamber and on the wafer holder without wafers, before coating the wafers (4 per ALD run due to restriction in the dimensions of the chamber) and annealing them in the same furnace run. Wafers from the other batch were coated without chamber pre-conditioning. The differences between the two batches of wafers are clear. Wafers coated without pre-conditioning follow a peculiar trend in

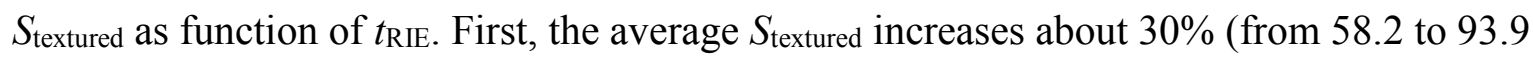
$\mathrm{cm} \mathrm{s}^{-1}$ ) increasing $t_{\mathrm{RIE}}$ from $30 \mathrm{~s}$ to $t_{\mathrm{RIE}} 2 \mathrm{~min}$. Then, it reaches a maximum of $222.1 \mathrm{~cm} \mathrm{~s}^{-1}$ for $t_{\mathrm{RIE}}=4 \mathrm{~min}$. For further increasing $t_{\mathrm{RIE}}, S_{\text {textured }}$ decreases until it reaches $68.5 \mathrm{~cm} \mathrm{~s}^{-1}$ for $t_{\mathrm{RIE}}=$ $16 \mathrm{~min}$, a value similar to the average measured for $t_{\mathrm{RIE}}=1 \mathrm{~min}$. A decrease in $\tau_{\mathrm{eff}}$ followed by an increase for longer RIE times has been reported by Otto et al. [25]. Such a trend seems counterintuitive, given that by increasing $t_{\mathrm{RIE}}$ the surface area of the textured wafers increases and so should the total surface recombination. Slight variations in the etching parameters used to fabricate 'shallow', 'intermediate' and 'deep' nanostructures may account for the observed trends in terms of $\tau_{\text {eff. }}$ We note here that the only parameter we varied in our RIE processing is $t_{\mathrm{RIE}}$. In addition, we note that the standard deviation measured on surfaces with $t_{\mathrm{RIE}} \geq 2 \mathrm{~min}$ is too large to draw solid conclusions about differences in surface recombination velocity. The batch of wafers coated following chamber pre-conditioning shows rather different results. First, $S_{\text {textured }}$ increased monotonically with increasing $t_{\mathrm{RIE}}$, from $15.5 \mathrm{~cm} \mathrm{~s}^{-1}$ of the planar reference to $33.1 \mathrm{~cm} \mathrm{~s}^{-1}$ for $t_{\mathrm{RIE}}=16 \mathrm{~min}$. Second, the magnitude of $S_{\text {textured }}$ is more than half of that of the corresponding wafer from the other batch. Third, the uniformity of the passivation over the full wafers is much higher, since the standard deviation of $S_{\text {textured }}$ has

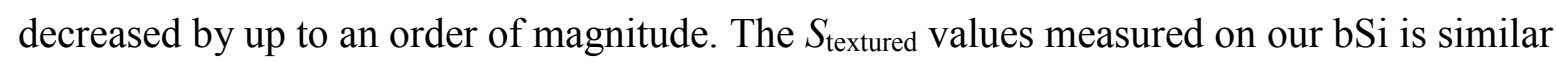
to that achieved by Plakhotnyuk et al. on the same type of substrates and using the same fabrication parameters, and the relative difference in $S_{\text {textured }}$ between planar and bSi samples is about $30 \%$ higher than the data reported by Otto et al. on double-side textured, p-type substrates. Current work focuses on improving the RIE recipe to further decrease sub-surface 
damage and thus recombination at the textured surfaces. Nonetheless, the results presented here indicate that an appropriate pre-conditioning of the ALD chamber in our cleanroom facility is necessary to ensure: (i) the highest possible quality of passivation when using $\mathrm{Al}_{2} \mathrm{O}_{3}$; and (ii) the batch-to-batch reproducibility of the passivation, which is necessary in order to be able to compare data from wafers coated in different ALD runs. In addition, we note that such chamber pre-conditioning is likely to be required in similar academic facilities characterized by a very broad spectrum of process flows, substrate and materials, whereas it is probably not necessary in industrial facilities dedicated to $e . g$. production of solar cells.

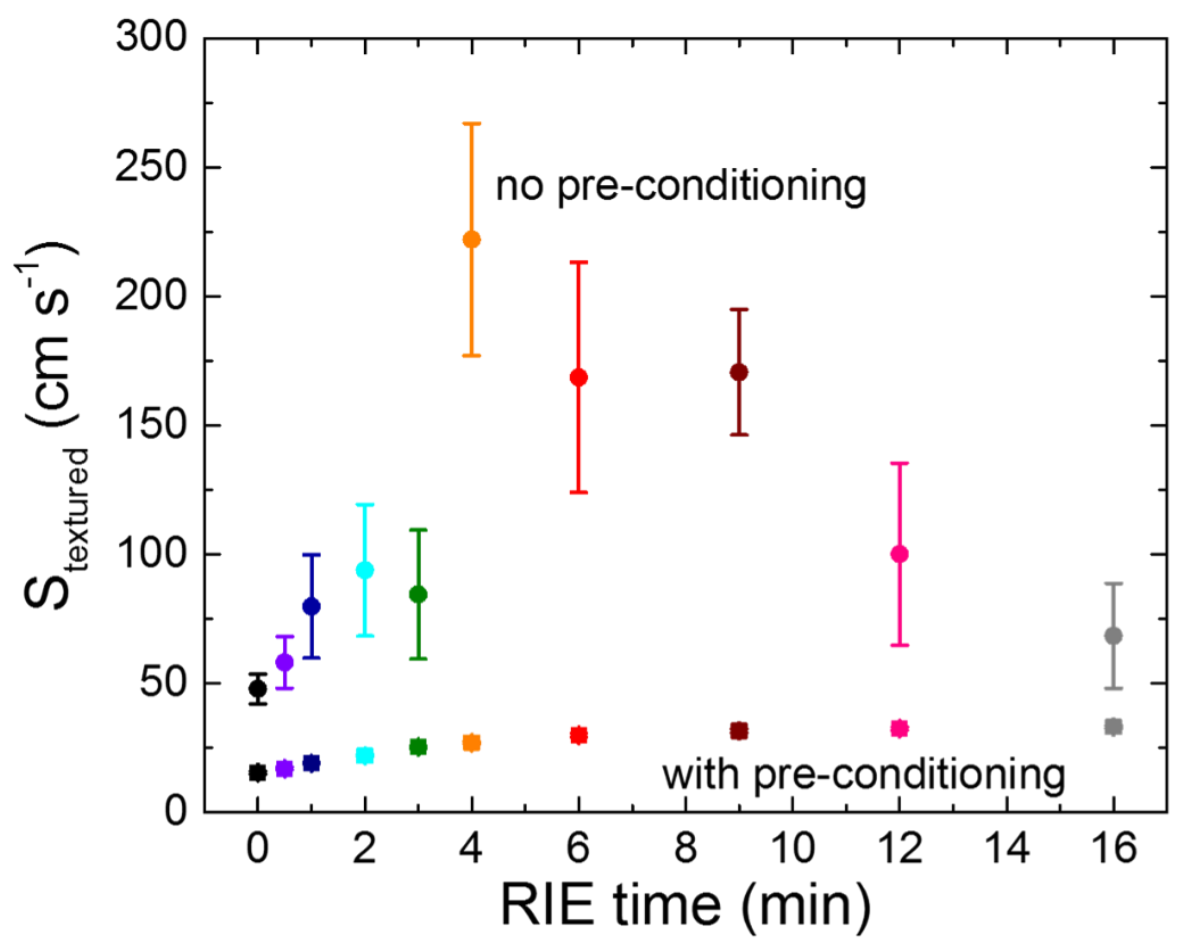

Figure 6. Surface recombination velocity $S_{\text {textured }}$ of textured Si surfaces as function of etching time $t_{\text {RIE. }}$ Wafers coated without ALD chamber pre-conditioning (circles) show a peculiar trend with a minimum in $\tau_{\text {eff }}$ for $t_{\mathrm{RIE}}=4 \mathrm{~min}$, and relative standard deviations of up to $40 \%$. Wafers coated with ALD chamber pre-conditioning (squares) display monotonically increasing $S_{\text {textured }}$ for increasing $t_{\mathrm{RIE}}$ and a much smaller relative standard deviation.

\section{Conclusions}

In this work, we investigated formation of blisters on $\mathrm{Al}_{2} \mathrm{O}_{3}$ films deposited on planar and nanostructured Si (black Si) surfaces. We found that the ALD deposition temperature and the choice of equipment for the post-ALD thermal treatment result in considerable variations in size and number density of blisters. In particular, lower $T_{\mathrm{ALD}}$ and lower $T_{\mathrm{ann}}$ in a tube furnace 
results in the lowest blister size. The area fraction covered by the blisters remained lower than $2 \%$. Nonetheless, effective lifetime mapping revealed that the surface recombination velocity at the blisters is at least 20 times larger than at the non-blistered surface, with absolute values similar to those of non-passivated Si surfaces. The much larger $S_{\text {eff }}$ at the blisters and potential contacting problems from film delamination justify the efforts in minimizing blistering. We found that a short RIE process is able to inhibit formation of blisters, likely thanks to a reduction of shear as driving force for delamination. We found that such a treatment does not increase $S_{\text {eff }}$ within experimental deviations, and therefore is an interesting alternative to the other modifications to ALD and post-ALD processing that result in a lower content of hydrogen as side effect. The same RIE process was used to fabricate nanostructured black Si surfaces showing excellent antireflective properties and good IR light trapping for the longest etching time of $16 \mathrm{~min}$. An ALD chamber pre-conditioned routine was found to be necessary to decrease surface recombination velocity of the bSi surface, as well as to improve reproducibility of lifetime data between wafers coated in different batches. These results provide guidelines on avoiding blistering at the $\mathrm{Si} / \mathrm{Al}_{2} \mathrm{O}_{3}$ interface without affecting significantly the surface recombination velocity. In particular, a short RIE treatment before deposition of passivation stacks including $\mathrm{Al}_{2} \mathrm{O}_{3}$ may be of interest to inhibit blistering and film delamination.

\section{Author Information}

Corresponding Authors: benian@nanotech.dtu.dk. Tel: +45 45258167

\section{Notes}

The authors declare no competing financial interest.

\section{Acknowledgements}

This project is supported by funding from the EUDP (project number 64016-0030). B.I. thanks Io Mizushima at IPU for help with the spectrophotometer measurements.

\section{References}

[1] A.G. Aberle, Surface passivation of crystalline silicon solar cells: a review, Prog. Photovoltaics Res. Appl. 8 (2000) 473-487. doi:10.1002/1099159X(200009/10)8:5<473::AID-PIP337>3.0.CO;2-D.

[2] R.S. Bonilla, B. Hoex, P. Hamer, P.R. Wilshaw, Dielectric surface passivation for silicon solar cells: A review, Phys. Status Solidi Appl. Mater. Sci. 214 (2017). 
doi:10.1002/pssa.201700293.

[3] M.A. Green, A.W. Blakers, E.M. Keller, S.R. Wenham, High-efficiency silicon solar cells, IEEE Trans. Electron Devices. 31 (1984) 679-683. doi:10.1109/TED.1984.21589.

[4] G. Dingemans, W.M.M. Kessels, Status and prospects of $\mathrm{Al}_{2} \mathrm{O}_{3}$-based surface passivation schemes for silicon solar cells, J. Vac. Sci. Technol. A Vacuum, Surfaces, Film. 30 (2012) 40802. doi:10.1116/1.4728205.

[5] A. Bansal, P. Srivastava, B.R. Singh, On the surface passivation of c-silicon by RF sputtered $\mathrm{Al}_{2} \mathrm{O}_{3}$ for solar cell application, (2015) 639-645. doi:10.1007/s10854-0142439-4.

[6] S. Chen, L. Tao, L. Zeng, R. Hong, RF Magnetron Sputtering Aluminum Oxide Film for Surface Passivation on Crystalline Silicon Wafers, 2013 (2013).

[7] S. Miyajima, J. Irikawa, A. Yamada, M. Konagai, High Quality Aluminum Oxide Passivation Layer for Crystalline Silicon Solar Cells Deposited by Parallel-Plate Plasma-Enhanced Chemical Vapor Deposition, (2010). doi:10.1143/APEX.3.012301.

[8] J. Schmidt, F. Werner, B. Veith, D. Zielke, S. Steingrube, Advances in the Surface Passivation of Silicon Solar Cells, Energy Procedia. 15 (2012) 30-39. doi:10.1016/j.egypro.2012.02.004.

[9] D. Kania, P. Saint-cast, D. Wagenmann, M. Hofmann, J. Rentsch, R. Preu, INDUSTRIAL NEGATIVELY CHARGED c-Si SURFACE PASSIVATION BY INLINE PECVD AlO, (2009) 2275-2278.

[10] R. Hezel, Low-Temperature Surface Passivation of Silicon for Solar Cells, J. Electrochem. Soc. 136 (1989) 518. doi:10.1149/1.2096673.

[11] G. Agostinelli, A. Delabie, P. Vitanov, Z. Alexieva, H.F.W. Dekkers, S. De Wolf, G. Beaucarne, Very low surface recombination velocities on p-type silicon wafers passivated with a dielectric with fixed negative charge, Sol. Energy Mater. Sol. Cells. 90 (2006) 3438-3443. doi:10.1016/j.solmat.2006.04.014.

[12] B. Hoex, J. Schmidt, P. Pohl, M.C.M. van de Sanden, W.M.M. Kessels, Silicon surface passivation by atomic layer deposited $\mathrm{Al}_{2} \mathrm{O}_{3}$, J. Appl. Phys. 104 (2008) 44903 . doi:10.1063/1.2963707.

[13] B. Hoex, J.J.H. Gielis, M.C.M. Van De Sanden, W.M.M. Kessels, On the surface passivation mechanism by the negative-charge-dielectric On the c-Si surface passivation mechanism by the negative-charge- dielectric $\mathrm{Al}_{2} \mathrm{O}_{3}, 113703$ (2012). doi:10.1063/1.3021091. 
[14] H. Huang, J. Lv, Y. Bao, R. Xuan, S. Sun, S. Sneck, Solar Energy Materials \& Solar Cells e ffi ciency loss mechanisms analysis and roadmap to $24 \%$, Sol. Energy Mater. Sol. Cells. 161 (2017) 14-30. doi:10.1016/j.solmat.2016.11.018.

[15] J. Benick, B. Hoex, M.C.M. Van De Sanden, W.M.M. Kessels, O. Schultz, S.W. Glunz, High efficiency n-type Si solar cells on $\mathrm{Al}_{2} \mathrm{O}_{3}$-passivated boron emitters, Appl. Phys. Lett. 92 (2008) 1-4. doi:10.1063/1.2945287.

[16] J. Benick, A. Richter, R. Müller, H. Hauser, F. Feldmann, P. Krenckel, S. Riepe, F. Schindler, M.C. Schubert, M. Hermle, A.W. Bett, S.W. Glunz, High-Efficiency n-Type HP mc Silicon Solar Cells, IEEE J. Photovoltaics. 7 (2017) 1171-1175. doi:10.1109/JPHOTOV.2017.2714139.

[17] H. Jansen, M. De Boer, R. Legtenberg, M. Elwenspoek, The black silicon method: A universal method for determining the parameter setting of a fluorine-based reactive ion etcher in deep silicon trench etching with profile control, J. Micromechanics Microengineering. 5 (1995) 115-120. doi:10.1088/0960-1317/5/2/015.

[18] H. Savin, P. Repo, G. Von Gastrow, P. Ortega, E. Calle, M. Garín, R. Alcubilla, Black silicon solar cells with interdigitated back-contacts achieve $22.1 \%$ efficiency, Nat. Nanotechnol. 10 (2015) 624-628. doi:10.1038/nnano.2015.89.

[19] R.S. Davidsen, H. Li, A. To, X. Wang, A. Han, J. An, J. Colwell, C. Chan, A. Wenham, M.S. Schmidt, A. Boisen, O. Hansen, S. Wenham, A. Barnett, Black silicon laser-doped selective emitter solar cell with $18.1 \%$ efficiency, Sol. Energy Mater. Sol. Cells. 144 (2016) 740-747. doi:10.1016/j.solmat.2015.10.018.

[20] S. Koynov, M.S. Brandt, M. Stutzmann, Black nonreflecting silicon surfaces for solar cells, Appl. Phys. Lett. 88 (2006) 88-91. doi:10.1063/1.2204573.

[21] B. Kafle, T. Freund, A. Mannan, L. Clochard, E. Duffy, S. Werner, P. Saint-Cast, M. Hofmann, J. Rentsch, R. Preu, Plasma-free Dry-chemical Texturing Process for Highefficiency Multicrystalline Silicon Solar Cells, Energy Procedia. 92 (2016) 359-368. doi:10.1016/j.egypro.2016.07.113.

[22] R.S. Davidsen, J. Ormstrup, M.L. Ommen, P.E. Larsen, M.S. Schmidt, A. Boisen, Ø. Nordseth, O. Hansen, Angle resolved characterization of nanostructured and conventionally textured silicon solar cells, Sol. Energy Mater. Sol. Cells. 140 (2015) 134-140. doi:10.1016/j.solmat.2015.04.001.

[23] R.S. Davidsen, P.T. Tang, I. Mizushima, S. Thorsteinsson, P.B. Poulsen, J. Frausig, O. Nordseth, O. Hansen, Black silicon solar cells with black bus-bar strings, Conf. Rec. IEEE Photovolt. Spec. Conf. 2016-Novem (2016) 2885-2888. 
doi:10.1109/PVSC.2016.7750183.

[24] K. Füchsel, M. Kroll, M. Otto, M. Steglich, A. Bingel, T. Käsebier, R.B. Wehrspohn, E.B. Kley, T. Pertsch, A. Tünnermann, Black Silicon Photovoltaics, Phot. Manag. Sol. Cells. (2015) 117-151. doi:10.1002/9783527665662.ch5.

[25] M. Otto, M. Algasinger, H. Branz, B. Gesemann, T. Gimpel, K. Füchsel, T. Käsebier, S. Kontermann, S. Koynov, X. Li, V. Naumann, J. Oh, A.N. Sprafke, J. Ziegler, M. Zilk, R.B. Wehrspohn, Black Silicon Photovoltaics, Adv. Opt. Mater. 3 (2015) 147164. doi:10.1002/adom.201400395.

[26] Y. Bao, S. Li, G. von Gastrow, P. Repo, H. Savin, M. Putkonen, Effect of substrate pretreatments on the atomic layer deposited $\mathrm{Al}_{2} \mathrm{O}_{3}$ passivation quality, J. Vac. Sci. Technol. A Vacuum, Surfaces, Film. 33 (2015) 01A123. doi:10.1116/1.4901456.

[27] O. Beldarrain, M. Duch, M. Zabala, J.M. Rafi, M.B. Gonzalez, F. Campabadal, Blistering of atomic layer deposition $\mathrm{Al}_{2} \mathrm{O}_{3}$ layers grown on silicon and its effect on metal-insulator-semiconductor structures, J. Vac. Sci. Technol. A Vacuum, Surfaces, Film. 31 (2013) 01A128-01A128-6. doi:10.1116/1.4768170.

[28] F. Lebreton, R. Lachaume, P. Bulkin, F. Silva, S.A. Filonovich, E. V. Johnson, P.R.I. Cabarrocas, Deleterious electrostatic interaction in silicon passivation stack between thin $\mathrm{ALD} \mathrm{Al}_{2} \mathrm{O}_{3}$ and its a-SiN $: \mathrm{H}$ capping layer: Numerical and experimental evidences, Energy Procedia. 124 (2017) 91-98. doi:10.1016/j.egypro.2017.09.328.

[29] J. Thurn, R.F. Cook, Mechanical and thermal properties of physical vapour deposited alumina films, J. Mater. Sci. 9 (2004) 4799-4807.

[30] D. Xie, Z. Wang, J. Sun, J. Li, E. Ma, Z. Shan, In situ study of the initiation of hydrogen bubbles at the aluminium metal / oxide interface, Nat. Mater. 14 (2015) 899904. doi:10.1038/NMAT4336.

[31] M. Broas, H. Jiang, A. Graff, T. Sajavaara, V. Vuorinen, M. Paulasto-kröckel, Blistering mechanisms of atomic-layer-deposited $\mathrm{AlN}$ and $\mathrm{Al}_{2} \mathrm{O}_{3}$ films, Appl. Phys. Lett. 141606 (2017). doi:10.1063/1.4994974.

[32] L. Hennen, E.H. a Granneman, W.M.M. Kessels, Analysis of Blister Formation in Spatial ALD $\mathrm{Al}_{2} \mathrm{O}_{3}$ for Silicon Surface Passivation, Photovolt. Spec. Conf. (PVSC), 2012 38th IEEE. (2011) 1049-1054. doi:10.1109/PVSC.2012.6317783.

[33] B. Vermang, $\mathrm{H}$. Goverde, On the blistering of atomic layer deposited $\mathrm{Al}_{2} \mathrm{O}_{3}$ as $\mathrm{Si}$ surface passivation, ... (PVSC), 2011 37th .... 162106 (2011) 3562-3567. doi:10.1109/PVSC.2011.6185916.

[34] B. Vermang, H. Goverde, A. Uruena, A. Lorenz, E. Cornagliotti, A. Rothschild, J. 
John, J. Poortmans, R. Mertens, Blistering in ALD Al2O3passivation layers as rear contacting for local Al BSF Si solar cells, Sol. Energy Mater. Sol. Cells. 101 (2012) 204-209. doi:10.1016/j.solmat.2012.01.032.

[35] Li, S., Repo, P., Von Gastrow, G., Bao, Y., Savin, H., Effect of ALD reactants on blistering of aluminum oxide films on crystalline silicon, in: Conf. Rec. IEEE Photovolt. Spec. Conf., 2013.

[36] F. Lebreton, A. Zauner, P. Bulkin, F. Silva, S. Filonovich, P.R. i Cabarrocas, Benefits of a thermal drift during atomic layer deposition of $\mathrm{Al}_{2} \mathrm{O}_{3}$ for c-Si passivation, in: 43rd IEEE Photovolt. Spec. Conf., 2017. doi:10.1021/la503406v.

[37] G. von Gastrow, R. Alcubilla, P. Ortega, M. Yli-Koski, S. Conesa-Boj, A. Fontcuberta i Morral, H. Savin, Analysis of the Atomic Layer Deposited $\mathrm{Al}_{2} \mathrm{O}_{3}$ field-effect passivation in black silicon, Sol. Energy Mater. Sol. Cells. 142 (2015) 29-33. doi:10.1016/j.solmat.2015.05.027.

[38] M.M. Plakhotnyuk, M. Gaudig, R.S. Davidsen, J.M. Lindhard, J. Hirsch, D. Lausch, M.S. Schmidt, E. Stamate, O. Hansen, Low surface damage dry etched black silicon, J. Appl. Phys. 122 (2017). doi:10.1063/1.4993425.

[39] B. Kafle, T. Freund, A. Mannan, L. Clochard, E. Duffy, S. Werner, P. Saint-Cast, M. Hofmann, J. Rentsch, R. Preu, Plasma-free Dry-chemical Texturing Process for Highefficiency Multicrystalline Silicon Solar Cells, Energy Procedia. 92 (2016) 359-368. doi:10.1016/j.egypro.2016.07.113. 